\title{
I.UMIBUNG
}

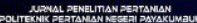

\section{Peningkatan Produksi Tanaman Bangun-Bangun (Coleus amboinicus l.) Daerah Sumatera Barat Dengan Penggunaan Kompos Eceng Gondok}

\author{
Ramond Siregar $^{1}$, Nelzi Fati ${ }^{1}$, Sentot Wahono ${ }^{2}$ dan Yun Sondang ${ }^{3}$ \\ ${ }^{1}$ Program Studi Budi Daya Ternak, Politeknik Pertanian Negeri Payakumbuh \\ ${ }^{2}$ Program Studi Hortikultura, Politeknik Pertanian Negeri Payakumbuh \\ ${ }^{3}$ Program Studi Budidaya Tanaman Pangan, Politeknik Pertanian Negeri Payakumbuh \\ Jl. Raya Negara Km. 7 Tanjung Pati, 26271, Payakumbuh \\ Korespondensi: garr_fams@yahoo.co.id
}

$\begin{array}{ll}\text { Diterima } & : \text { 21 Desember } 2018 \\ \text { Disetujui } & : 29 \text { Desember } 2018 \\ \text { Diterbitkan } & : \text { 31 Januari } 2019\end{array}$

\begin{abstract}
ABSTRAK
Tujuan penelitian adalah mempelajari potensi daun bangun-bangun yang ditanam di beberapa daerah Sumatera Barat, kandungan gizinya dan untuk mengetahui formulasi pupuk yang tepat untuk meningkatkan produksi tanaman bangun-bangun. Penelitian dilaksanakan selama 6 bulan di Laboratorium Peternakan Unand Padang, Laboratorium Peternakan dan Kebun Percobaan Politani Negeri Payakumbuh. Metode penelitian ini menggunakan Rancangan Acak Lengkap dengan lima perlakuan dan 4 ulangan. Adapun perlakuan pupuk kompos eceng gondoknya adalah A (Tanpa pupuk $\mathrm{N}(0 \%)+$ Kompos eceng gondok 100\%), B (Pupuk N 25\% + Kompos eceng gondok 75\%), C (Pupuk N $50 \%+$ Kompos eceng gondok 50\%), D (Pupuk N 75\% + Kompos eceng gondok 25\%) dan E (Pupuk N 100\% + Tanpa Kompos (0\%). Adapun parameter yang diukur adalah tinggi tanaman, jumlah cabang, bunga, laju tumbuh relatif, berat segar (gr/tanaman). Hasil penelitian yang didapatkan berupa data identifikasi tanaman bangun-bangun dan kandungan gizi daun bangun-bangun untuk daerah Padang, Padang Panjang dan Payakumbuh. Identifikasi tanaman daun bangun-bangun terdiri dari: keadaan lingkungan dan deskripsi tanaman. Kandungan gizi tanaman bangun-bangun protein kasar 19, 24 - 24, 98\%; lemak kasar 4,21 - 5,98\%, Serat kasar 9,08 -14,17\%, Abu 11,34 $-16,25 \%$, Ca 1,992 - 2,133\%, P 0,194 - 0,337 dan gross energi (GE) 3820 - 4070,01 $\mathrm{kal} / \mathrm{g}$. Dosis pupuk eceng gondok berpengaruh nyata $(\mathrm{P}<0.05)$ terhadap laju tumbuh relatif, berat segar (gr/tanaman), sedangkan terhadap tinggi tanaman, cabang primer, dan bunga tidak berpengaruh nyata $(\mathrm{P}>0.05)$. Dari hasil penelitian ini dapat disimpulkan bahwa penggunaan $100 \%$ kompos eceng gondok dapat meningkatkan laju pertumbuhan relatif, bobot berangkasan segar (gr/tanaman) dan bobot berangkasan kering (gr/tanaman), sedangkan perbandingan pupuk kompos tidak berpengaruh secara nyata $(\mathrm{P}>0.05)$ terhadap tinggi tanaman dan jumlah cabang.
\end{abstract}

Keywords: Bangun-bangun, Laktagogum, Nutrisi, Eichornia Crassipes Solm 


\title{
I.UMIBUNG
}

\section{son}

\begin{abstract}
The objectives of this research are to study a potential and nutrient contains of bangunbangun especially in west Sumatra region also to determine the exact formulation of fertilizer to increase crop production. The research was conducted approximately 6 months in laboratory and experimental field of Andalas University and also in Agricultural Polytechnic of Payakumbuh. They were 3 stage of research; 1) identification of potential of leaves of bangun-bangun was planted in Padang, Padang Panjang and Payakumbuh, 2) Nutrients contain analysis and 3) determining the exact formulation of fertilizer to increase crop production. This research used a completely randomized design with five treatments and four replications. The level of treatments is A (Without fertilizer N (0\%) + Eichornia Crassipes Solm $100 \%), B(25 \% N$ fertilizer + Eichornia Crassipes Solm $75 \%$ ), C (fertilizer N $50 \%+50 \%$ Eichornia Crassipes Solm), D (75\% N fertilizer + Eichornia Crassipes Solm $25 \%)$ and E (fertilizer N + Eichornia Crassipes Solm (0 \%). The parameters measured were plant height, number of branches, number of flowers, relative growth rate and fresh weight (g/plant). The results of this research comprises 1) Data of bangun-bangun plants description relate with its circumstance, and 2) Nutrients contents of plant, consist of: Crude protein 19.24-24.98\%, ether extract 4,2-5,98\%, Crude fiber 9,08-14,17\%, Ash 11,34-16,25\%, Ca 1,992-2,133\%, P 0,194-0,337 and gross energi (GE) 3820-4070,01 kal/g. 3) indicate that the Eichornia Crassipes Solm significantly $(P<0.05)$ on relative growth rate, fresh weight (g/plant), in other side the plant height, primary branches, and flowers did not significantly $(P>0: 05)$.
\end{abstract}

Keywords: Bangun-bangun, Laktagogum, Nutrition, Eichornia Crassipes Solm

\section{PENDAHULUAN}

Upaya penggalian, penelitian, dan pengembangan tanaman obat tradisional pada pakan ternak sudah mulai diterapkan. Penggunaan tanaman ini lebih bertujuan untuk meningkatkan kesehatan dan produksi ternak, namun masih sedikit informasi tentang kesehatan peranakan yang dapat diterapkan pada peternak. Tanaman bangun-bangun (Coleus amboinicus L.) merupakan salah satu tanaman obat yang banyak khasiatnya. Tanaman bangun-bangun berasal dari daerah Sumatera Utara dan selanjutnya dibawa oleh pendatang ke daerah Sumatera Barat.

Tanaman bangun-bangun sudah lama dikenal dalam masyarakat Tapanuli sebagai menu sayur-sayuran sehari-hari untuk meningkatkan stamina dan memperlancar produk air susu pada ibu melahirkan (Asiah, 2011). Daunnya memiliki aroma tertentu sehingga disebut tanaman aromatik dan mengandung minyak atsiri (Plantamor.com 2008). Menurut Kaliappan (2008) tanaman ini mengandung berbagai jenis flavonoid yaitu quercetin, apigenin, luteolin, salvigenin, genkwanin. Arsiki (2009) menyatakan 


\section{I.UMIBUNC}

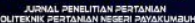

bahwa tanaman ini mengandung zat besi dan karotin yang tinggi, sehingga dengan konsumsi tanaman ini dapat meningkatkan kadar zat besi, kalium, seng, dan magnesium dalam ASI serta meningkatkan berat badan bayi (Mangathayaru, Thirunurgan, dan Patel, 2008).

Pada ternak babi penggunaan tepung bangun-bangun dapat memperbaiki nilai konversi ransum induk menyusui dan meningkatkan pertambahan bobot badan anak (Sinaga dan Perdana, 2010), (Togatorop, 2011). Namun demikian apakah pengaruh terhadap ibu menyusui dan ternak babi akan sama terhadap ternak lain, untuk itu perlu penelitian lebih lanjut untuk mengetahui kandungan kimia daun bangun-bangun.

Latar belakang penelitian ini berdasarkan hasil penelitian yang telah dicobakan oleh beberapa peneliti pada ternak babi memperlihatkan pengaruh yang berbeda walaupun dosis pemberiannya sama. Kemungkinan hal ini disebabkan oleh kandungan hara dan gizi tanaman bangun-bangun berbeda antara satu tempat dan tempat lainnya. Disamping itu khasiat tanaman yang belum dikenal oleh masyarakat umum dan tanaman mudah berkembang biak.

Kambing merupakan makanan sumber protein hewani yang banyak digemari masyarakat luas, namun pemeliharaan yang kurang intensif terutama pasca melahirkan akan menurunkan reproduksi kambing (Partodihardjo, 1982). Perlu penelitian menyeluruh yang dimulai dari mengkaji potensi tanaman, teknologi budidaya tanaman sampai kepada pemanfaatannya untuk pakan ternak kambing.

Pemecahan masalah produksi sumber protein hewani dengan pemanfaatan bahan baku tanaman bangun-bangun merupakan salah satu teknologi pertanian berkelanjutan yang efektif dalam rangka meningkatkan produksi ternak yang aman.

\section{METODE PENELITIAN}

\section{Skema Penelitian}

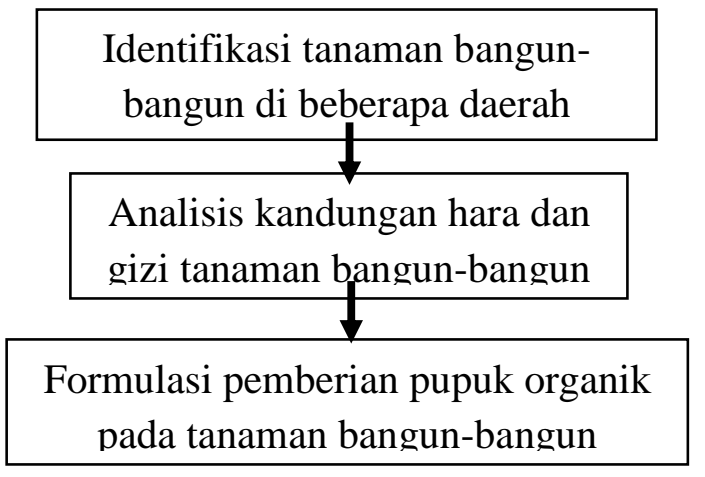




\section{I.UMIBUNG}

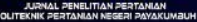

1. Identifikasi tanaman bangun-bangun di beberapa daerah Sumatera Barat

2. Analisis hara dan gizi tanaman Bangun-bangun di beberapa daerah Sumatera Barat

3. Formulasi pemberian pupuk organik pada budidaya tanaman bangun-bangun.

\section{Percobaan Tahap 1 Tahun 1}

Identifikasi Tanaman Bangun-bangun di beberapa daerah Sumatera Barat

- Waktu dan Tempat

Penelitian dilaksanakan di beberapa daerah Sumatera Barat (Padang, Payakumbuh dan Padang Panjang) dari bulan April sampai Mei 2013.

- Bahan dan Alat

Bahan yang digunakan tanaman bangun-bangun di tiga lokasi, sedangkan alat yang dibutuhkan sekop, meteran dan alat tulis.

- Metode Percobaan

Tanaman bangun-bangun yang berada di beberapa daerah dengan ketinggian berbeda antara lain Padang (rendah), Payakumbuh (sedang), dan Padang Panjang (tinggi) diidentifikasi morfologi batang, daun, bunga, dan akarnya.
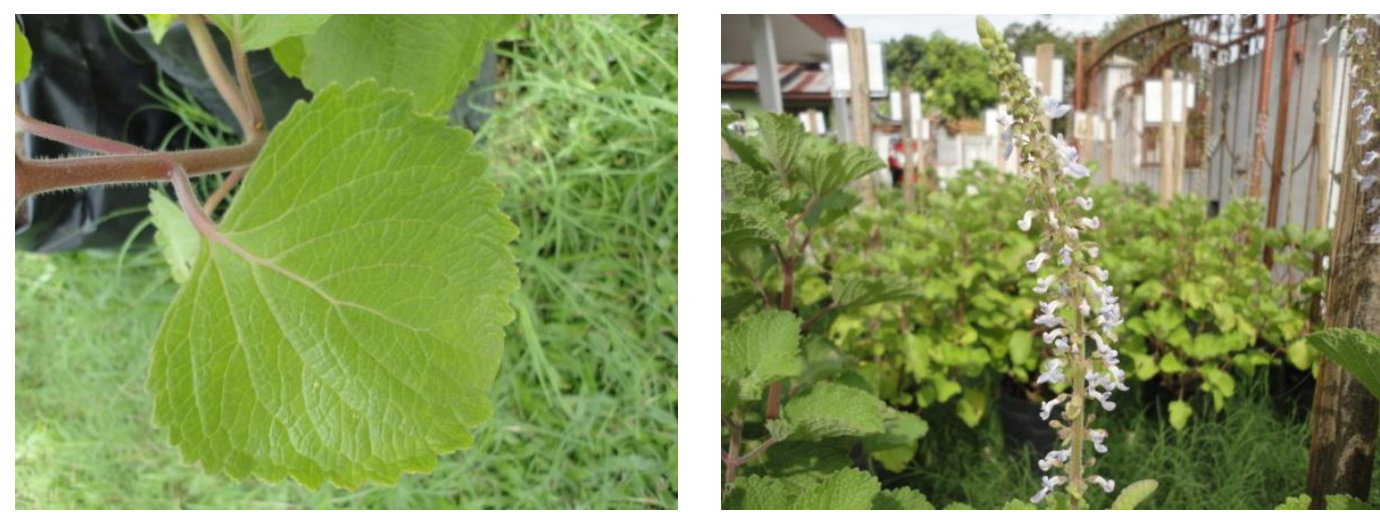

Gambar 1. Daun dan bunga tanaman bangun-bangun

\section{Percobaan Tahap 2 Tahun 1}

Analisa kandungan nutrisi daun Bangun-bangun di beberapa daerah Sumatera Barat

- Waktu dan Tempat

Penelitian dilaksanakan di laboratorium Peternakan Universitas Andalas dari bulan Juni sampai Juli 2013.

- Bahan dan Alat

Bahan yang digunakan tanaman bangun-bangun yang berasal dari tiga lokasi, bahanbahan kimia untuk analisa hara dan gizi tanaman. 


\section{I.UMIBUNG}

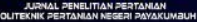

Alat yang digunakan gunting stek, oven, timbangan digital, dan alat-alat laboratorium.

- Metode Percobaan

Tanaman bangun-bangun yang berasal dari beberapa daerah dengan ketinggian berbeda antara lain Padang (rendah), Payakumbuh (sedang), dan Padang Panjang (tinggi) dicabut dan diambil sebagai sampel untuk analisa kandungan nutrisi daun bangun-bangun. Hasil yang terbaik digunakan untuk budidaya tanaman pada penelitian tahap ketiga.

Pengujian komponen nutrisi dengan menggunakan analisis proksimat (Nollet, 1996 ; Nielsen, 1998 ; AOAC, 1984).

Pengamatan komponen nutrisi meliputi protein kasar, serat kasar, lemak, abu, Ca, P, dan GE.

\section{Percobaan Tahap 3 Tahun 1}

Formulasi Pemberian Pupuk Organik pada Budidaya Tanaman Bangun-bangun

- Waktu dan Tempat

Penelitian dilaksanakan di kebun percobaan Politeknik Negeri Payakumbuh mulai bulan Agustus sampai November 2013.

- Bahan dan Alat

Bahan yang digunakan bibit tanaman bangun-bangun hasil penelitian tahap 2, tanah top soil, kompos, pupuk Urea, SP-36, dan $\mathrm{KCl}$.

Alat yang digunakan polibag, cangkul, meteran, oven, timbangan digital, dan timbangan $10 \mathrm{~kg}$.

- Rancangan Percobaan

Percobaan dilakukan menggunakan Rancangan acak kelompok dengan 4 ulangan. Perlakuan :

$\mathrm{A}=$ Tanpa pupuk $\mathrm{N}(0 \%)+$ Kompos eceng gondok $100 \%$

$\mathrm{B}=$ Pupuk N 25\% + Kompos eceng gondok $75 \%$

$\mathrm{C}=$ Pupuk N 50\% + Kompos eceng gondok 50\%

$\mathrm{D}=$ Pupuk N 75\% + Kompos eceng gondok 25\%

$\mathrm{E}=$ Pupuk N 100\% + Tanpa Kompos (0\%)

Setiap perlakuan terdiri dari 3 unit sampel, sehingga seluruhnya berjumlah 60 polibag. Data pengamatan dianalisis secara statistika dengan menggunakan sidik 


\section{I.UMIBUNC}

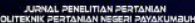

ragam dalam RAK pada taraf nyata $5 \%$ dan dilanjutkan dengan uji jarak berganda Duncan (DNMRT) pada taraf nyata $5 \%$.

- Pelaksanaan Percobaan

Stek tanaman dengan panjang $\pm 10 \mathrm{~cm}$ ditanam dalam polibag yang telah diisi tanah dan kompos sebanyak $8 \mathrm{~kg}$ sesuai dengan perlakuan. Setelah umur 2 minggu dilakukan pengamatan. Panen dilakukan setelah tanaman berumur 3 bulan.

- Pengamatan dan Pengumpulan Data

1. Tinggi Tanaman $(\mathrm{cm})$

Tinggi tanaman diamati pada umur 2 minggu setelah tanam sampai tanaman tanaman mengeluarkan malai.

2. Jumlah cabang (buah)

Jumlah cabang diamati pada umur 4 minggu setelah tanam yang dihitung dari cabang yang muncul dari batang utama.

\section{Laju Tumbuh Relatif (g hari $\left.{ }^{-1}\right)$}

Laju tumbuh relatif (LTR) yaitu peningkatan berat kering tanaman dalam suatu interval waktu dalam hubungannya dengan berat awal. Pengamatan laju tumbuh relatif dilakukan tiga kali, yaitu umur 4, 6, dan 8 minggu setelah tanam pada tanaman sampel. Caranya satu tanaman sampel dari masing-masing satuan perlakuan dicabut lalu seluruh bagian tanaman dibersihkan dan diovenkan selama 48 jam pada suhu $70^{\circ} \mathrm{C}$. Rumusnya :

$$
\begin{aligned}
\mathrm{LTR} & =\frac{\operatorname{Ln} W 2-\operatorname{Ln} W 1}{T 2-T 1} \\
\mathrm{~W}_{2} & =\text { Berat kering tanaman pada waktu } \mathrm{T} 2 \\
\mathrm{~W} 1 & =\text { Berat kering tanaman pada waktu } \mathrm{T} 1 \\
\mathrm{~T} 2 & =\text { Waktu pengamatan ke } 2 \text { (umur } 5 \text { dan } 7 \text { minggu) } \\
\mathrm{T} 1 & =\text { Waktu pengamatan ke } 1 \text { (umur } 3 \text { dan } 5 \text { minggu) }
\end{aligned}
$$

4. Bobot berangkasan tanaman

Bobot berangkasan tanaman diamati saat panen dengan cara memisahkan seluruh daun tanaman dan menimbangnya dalam keadaan segar, lalu dikeringkan dalam oven selama 48 jam pada suhu $70^{\circ} \mathrm{C}$ dan ditimbang kembali 


\section{I.UMIBUNC}

\section{HASIL DAN PEMBAHASAN}

Pertumbuhan tanaman bangun-bangun dapat dilihat dari tinggi tanaman, jumlah cabang primer, laju tumbuh relatif (LTR), bobot berangkasan daun, dan bobot berangkasan tanaman. Rataan dan analisis sidik ragam terhadap seluruh parameter pengamatan disajikan pada Tabel 1, 2 dan 3.

Tabel 1. Tinggi tanaman, jumlah cabang primer, dan laju tumbuh relatif (LTR), tanaman bangun-bangun

\begin{tabular}{cccc}
\hline Perlakuan & $\begin{array}{c}\text { Tinggi tanaman } \\
(\mathrm{cm})\end{array}$ & $\begin{array}{c}\sum \text { Cabang } \\
\text { primer }(\mathrm{bh})\end{array}$ & $\begin{array}{c}\text { Laju Tumbuh } \\
\text { Relatif }(\mathrm{g} / \mathrm{hr})\end{array}$ \\
\hline N 0\% + kompos 100\% (A) & 46,0 & 3,5 & $0,0574 \mathrm{a}$ \\
N 25\% + kompos 75\% (B) & 47,0 & 4,0 & $0,0323 \mathrm{~b}$ \\
N 50\% + kompos 50\% (C) & 55,5 & 3,3 & $0,0339 \mathrm{~b}$ \\
N 75\% + kompos 25\% (D) & 51,3 & 3,8 & $0,0276 \mathrm{~b}$ \\
N 100\% + kompos 0\% (E) & 52,8 & 4,5 & $0,0291 \mathrm{~b}$ \\
\hline
\end{tabular}

Ket: Angka-angka pada kolom yang diikuti oleh huruf kecil yang sama, berbeda tidak nyata menurut uji DNMRT pada taraf nyata $5 \%$

\section{Tinggi Tanaman}

Tinggi Tanaman bangun-bangun pada umur 9 minggu setelah tanam (sebelum fase berbunga) tercantum pada Tabel 3. Perlakuan pupuk pada tanaman bangun-bangun berpengaruh tidak nyata $(\mathrm{P}>0.05)$ terhadap tinggi tanaman (Tabel 3). Rataan tinggi tanaman tertinggi terdapat pada perlakuan pupuk N 50\% + kompos 50\% (C) yaitu 55.5 cm, dan diikuti perlakuan E, D, B, dan A.

Pengaruh tidak nyata dari perlakuan pupuk terhadap tinggi tanaman bangunbangun lebih disebabkan kondisi tanah masih mampu memberikan hara yang cukup terhadap pertumbuhan tanaman bangun-bangun. Disamping itu dosis kompos yang digunakan masih dosis yang minimal yaitu 5 t/ha.

\section{Jumlah Cabang Primer}

Cabang primer tanaman bangun-bangun pada umur 9 minggu setelah tanam memperlihatkan bahwa perlakuan pupuk pada tanaman bangun-bangun berpengaruh 


\section{I.UMIBUNC}

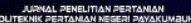

tidak nyata $(\mathrm{P}>0.05)$ terhadap cabang primer tanaman (Tabel 3). Rataan cabang primer tanaman yang tertinggi adalah 4.5 buah untuk dosis pupuk N 100\% + kompos 0\% (E).

Pertumbuhan cabang dari awal pertumbuhan menunjukkan jumlah cabang yang relatif tetap, hal ini terjadi karena dibatasi oleh jumlah buku yang ditanam yaitu 2 buku untuk semua perlakuan. Pemberian perlakuan pupuk tidak merubah sifat genetik tanaman bangun-bangun.

\section{Laju Tumbuh Relatif}

Laju Tumbuh Relatif (LTR) adalah laju pertumbuhan tanaman bangun-bangun per hari mulai umur 5 sampai 9 minggu setelah tanam disajikan pada Tabel 3. Rataan LTR tertinggi diperoleh pada perlakuan N 0\% + kompos 100\% (A), diikuti perlakuan C, B, E, dan D.

Hasil uji lanjut DNMRT memperlihatkan bahwa laju tumbuh relatif (LTR) tanaman bangun-bangun pada perlakuan pupuk N 0\% + kompos eceng gondok 100\% (A) berbeda nyata $(\mathrm{P}<0.05)$ dengan perlakuan pupuk lainnya $\mathrm{B}, \mathrm{C}, \mathrm{D}$, dan E. Pengaruh kompos $100 \%$ memberikan pengaruh yang nyata lebih tinggi dibandingkan perlakuan pupuk lainnya.

LTR yang paling tinggi terjadi pada perlakuan A yaitu komposisi pupuk $\mathrm{N} 0 \%+$ kompos eceng gondok $100 \%$. Hal ini disebabkan lebih tingginya hara yang diserap oleh tanaman, terutama $\mathrm{N}$, P, dan $\mathrm{K}$ sebagai hara makro yang dibutuhkan tanaman untuk pertumbuhan vegetatif. Hasil analisis kompos diperoleh kandungan hara sebesar 1,49\% $\mathrm{N}, 0,20 \% \mathrm{P}, 1,41 \% \mathrm{~K}, 40,36 \% \mathrm{C}$, dan rasio $\mathrm{C} / \mathrm{N}=27,09$ (Sondang, Anty dan Alfina, 2013).

Pemberian kompos memperbaiki struktur dan tekstur tanah, sehingga perkembangan akar tanaman lebih baik dan penyerapan hara yang berada di dalam tanah serta translokasi hara ke seluruh tanaman terjadi secara optimal. Selain memperbaiki sifat fisik dan kimia tanah, kompos eceng gondok juga meningkatkan sifat biologi tanah. Bahan organik merupakan makanan dari mikroorganisme, sehingga mikroorganisme tanah bisa berkembang baik dalam memperbaiki kondisi tanah. Brady (1990) menyatakan bahwa kompos juga merupakan sumber energi bagi sejumlah besar mikroorganisme yang hidup di dalam tanah. Mikroorganisme ini menjadikan hara yang ada dalam tanah termineralisasi sehingga menjadi tersedia bagi tanaman. 


\section{I.UMIBUNC}

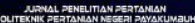

Kompos adalah bahan-bahan organik yang telah mengalami pelapukan, karena adanya interaksi mikroorganisme yang ada di dalamnya. Pembuatan kompos sebagian besar menggunakan aktivator. Aktivator kompos berfungsi mempercepat proses pengomposan. Dalam penelitian ini bahan aktivator yang digunakan adalah feses kambing. Mubandono (2003) menyatakan bahwa kompos berperan dalam memperbaiki sifat fisik, kimia, dan biologi tanah.

Tabel 2. Bobot berangkasan daun bangun-bangun segar dan kering pada umur 2,5 bulan setelah tanam

\begin{tabular}{ccc}
\hline Perlakuan & $\begin{array}{c}\text { Bobot berangkasan daun } \\
\text { segar (g) }\end{array}$ & $\begin{array}{c}\text { Bobot berangkasan daun } \\
\text { kering (g) }\end{array}$ \\
\hline N 0\% + kompos 100\% (A) N & $204,20 \mathrm{a}$ & $17,31 \mathrm{a}$ \\
$52 \%+\operatorname{kompos} 75 \%$ (B) N & $153,64 \mathrm{~b}$ & $12,70 \mathrm{~b}$ \\
$50 \%+\operatorname{kompos} 50 \%$ (C) N & $141,65 \mathrm{~b}$ & $11,80 \mathrm{bc}$ \\
$75 \%+\operatorname{kompos} 25 \%$ (D) N & $141,52 \mathrm{~b}$ & $11,41 \mathrm{bc}$ \\
$100 \%+\operatorname{kompos} 0 \%$ (E) & $153,25 \mathrm{~b}$ & $11,97 \mathrm{bc}$
\end{tabular}

Ket: Angka-angka pada kolom yang diikuti oleh huruf kecil yang sama, berbeda tidak nyata menurut uji DNMRT pada taraf nyata $5 \%$

\section{Bobot berangkasan daun (g)}

Bobot berangkasan daun pada umur 2,5 bulan setelah tanam tercantum pada Tabel 2. Perlakuan pupuk berpengaruh nyata $(\mathrm{P}<0.05)$ terhadap bobot berangkasan segar dan kering daun bangun-bangun. Rataan bobot berangkasan daun tertinggi adalah 20,42 g pada perlakuan pupuk N 0\%+kompos eceng gondok 100\% (A), diikuti perlakuan B, E, C, dan D.

Hasil uji lanjut DMRT memperlihatkan bahwa bobot kering daun bangunbangun pada perlakuan pupuk N 0\% + kompos eceng gondok 100\% (A) berbeda nyata $(\mathrm{P}<0.05)$ dengan perlakuan $\mathrm{B}(\mathrm{N} 25 \%+$ kompos eceng gondok $75 \%)$, C (N 50\% + kompos eceng gondok 50\%), D (N 75\% + kompos eceng gondok 25\%), dan E (N 100\% + kompos eceng gondok $0 \%$ ).

Daun merupakan produksi utama tanaman bangun-bangun yang akan digunakan sebagai pakan ternak pasca melahirkan. Peranan hara dalam tanah sangat mempengaruhi pertumbuhan vegetatif tanaman terutama bagian daun. Sumbangan hara dari kompos yang diberikan berpengaruh terhadap pertumbuhan tanaman. Hara $\mathrm{N}$ 


\section{I.UMIBUNC}

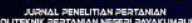

berperan dalam merangsang pertumbuhan hijau daun, sehingga fotosintesis dapat berlangsung secara optimal. Hara $\mathrm{K}$ berperan dalam memperbaiki sistem perakaran, sehingga akar dapat menyerap hara dari dalam tanah secara optimal. Kandungan hara N dan $\mathrm{K}$ yang tinggi dari kompos akan memperbaiki pertumbuhan vegetatif tanaman secara keseluruhan. Rata-rata bobot daun adalah $46-57 \%$ dari bobot tanaman bangunbangun.

Tabel 3. Bobot berangkasan segar dan kering tanaman bangun-bangun pada umur 2,5 bulan setelah tanam

\begin{tabular}{ccc}
\hline \multicolumn{1}{c}{ Perlakuan } & $\begin{array}{c}\text { Bobot berangkasan } \\
\text { tanaman segar }(\mathrm{g})\end{array}$ & $\begin{array}{c}\text { Bobot berangkasan } \\
\text { tanaman kering }(\mathrm{g})\end{array}$ \\
\hline N 0\% + kompos 100\% (A) & $444,00 \mathrm{a}$ & $35,80 \mathrm{a}$ \\
N 52\% + kompos 75\% (B) & $326,62 \mathrm{~b}$ & $25,37 \mathrm{~b}$ \\
N 50\% + kompos 50\% (C) & $307,80 \mathrm{~b}$ & $20,53 \mathrm{~b}$ \\
N 75\% + kompos 25\% (D) & $317,70 \mathrm{~b}$ & $23,01 \mathrm{~b}$ \\
N 100\% + kompos 0\% (E) & $333,60 \mathrm{~b}$ & $26,58 \mathrm{~b}$ \\
\hline
\end{tabular}

Ket: Angka-angka pada kolom yang diikuti oleh huruf kecil yang sama, berbeda tidak nyata menurut uji DNMRT pada taraf nyata $5 \%$

\section{Bobot berangkasan tanaman (g)}

Bobot berangkasan segar dan kering tanaman bangun-bangun pada umur 2,5 bulan tercantum pada Tabel 3. Perlakuan pupuk berpengaruh nyata $(\mathrm{P}<0.05)$ terhadap bobot berangkasan segar dan kering tanaman bangun-bangun (Tabel 3). Rataan bobot berangkasan segar dan kering tanaman tertinggi terdapat pada perlakuan pupuk $\mathrm{N}$ 0\%+kompos eceng gondok $100 \%$ (A) diikuti perlakuan pupuk E, B, D, dan C.

Hasil uji lanjut DMRT memperlihatkan bahwa bobot berangkasan segar dan kering tanaman bangun-bangun pada perlakuan N 0\%+kompos eceng gondok 100\% (A) berbeda nyata $(\mathrm{P}<0.05)$ dengan perlakuan $\mathrm{B}, \mathrm{C}, \mathrm{D}$, dan $\mathrm{E}$.

Kompos eceng gondok $100 \%$ memberikan pengaruh yang nyata terhadap bobot berangkasan tanaman. Kandungan hara $\mathrm{N}$ dan $\mathrm{K}$ yang tinggi dari kompos akan memperbaiki pertumbuhan vegetatif tanaman. Hal yang sama dungkapkan oleh Simbolon (2008) bahwa penggunaan kompos 100\% memberikan bobot berangkasan kering tanaman jagung yang tertinggi dibandingkan komposisi pupuk lainnya. 


\section{I.UMIBUNG}

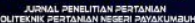

\section{KESIMPULAN}

\section{Kesimpulan}

1. Hasil identifikasi tanaman bangun-bangun di daerah Padang Panjang merupakan tempat yang paling memenuhi syarat tumbuh tanaman ini.

2. Penggunaan N 0\% + kompos eceng gondok $100 \%$ berpengaruh nyata $(\mathrm{P}<0.05)$ terhadap laju pertumbuhan relatif (LTR), bobot berangkasan daun, bobot berangkasan segar dan kering tanaman, namun berpengaruh tidak nyata $(\mathrm{P}>0.05)$ terhadap tinggi tanaman dan jumlah cabang primer tanaman bangun-bangun.

\section{Saran}

Diperlukan penelitian lanjutan untuk mengaplikasikan budidaya tanaman bangun-bangun dari tanaman polibag menjadi tanaman di lahan.

\section{REFERENSI}

AOAC, 1984.Official Metods of Analysis of the AOAC.Virginia:Inc., Arlington.

Asiah, N. 2011. Potensi daun bangun-bangun (Coleus amboinicus L.) sebagai lactagogum. Artikel.

Badan Meteorologi Klimatologi dan Geofisika Regional Wilayah VI Padang. 2013.

BP3K Kecamatan Payakumbuh. 2012. Kegiatan Revitalisasi Sistem Penyuluhan Pertanian. Program Peningkatan Kesejahteraan Petani.

Kaliappan ND, Viswanathan PK. Pharmacognostical studies on the leaves of Plectranthus amboinicus (Lour) spring. Int J Green Pharm. 2008;Vol 2, issue $3: 182-184$.

Mangathayaru, P.D. Thirunurgan, dan P.S. Patel. 2008. Essential oil composition of coleus amboinicus Lour. Indian Journal of Pharmaceutical Sciences. 2008;67(1):122-123.

Nielsen, S.S. 1998. Food Analysis, Second Edition, Kluwer Academic, New York.

Nollet, L.M.L. 1996. Handbook of Food Analysis, Vol 1. Marcel Dekker, Inc. New York.

Partodihardjo, S.1982.Ilmu Reproduksi Hewan.Edisi 1. Penerbit Mutiara Sumber Widjaya, Jakarta.

Plantamor. com. 2008. Bangun-bangun (Coleus amboinicus L.). Penerbit Plantamor. 


\section{I.UMIBUNG}

Siagian, MH dan M. Rahayu. 2000. Laporan Etnobotani Plectranthus amboinicus (Luor) Spreng di Daerah Batak Toba, Tapanuli Utara-Sumatera Utara. Makalah disajikan pada Kongres Nasional Obat Tradisional Indonesia, Surabaya, 20-22 November.

Sinaga, S dan A. Perdana. 2010. Pengaruh pemberian tepung bangun-bangun (Coleus amboinicus L.) pada ransum babi terhadap konversi ransum induk menyusui dan pertambahan bobot badan anak. Skripsi.

Togatorop, L. 2011. The effect of providing bangun-bangun meal (Coleus amboinicus. L) to digestible energy and nitrogen retention of feed in lactatingperiod pigs. http://lastiar-lastiar.blogspot.com/search/label/ bangun- bangun (Coleus amboinicus L.).

Warsiki, E., E. Damayanthy, R. Damanik. 2009. Karakteristik mutu sop daun torbangun (Coleus amboinicus L.) dalam kemasan kaleng dan perhitungan total migrasi bahan kemasan. J Tek Ind Pert. 2009; Vol 18(3):21-24 